\title{
AGENT-BASED MODELLING PADA STUDI KEPENDUDUKAN: POTENSI DAN TANTANGAN
}

\author{
(Agent-Based Modelling in Population Studies: Potentials and Challenges)
}

\author{
Tiodora Hadumaon Siagian ${ }^{1}$, Ari Purwanto Sarwo Prasojo² \\ ${ }^{1}$ Politeknik Statistika STIS \\ ${ }^{2}$ Pusat penelitian Kependudukan LIPI \\ Jl. Otto Iskandardinata No. 64C, Jakarta - 13330 \\ E-mail: theo@stis.ac.id
}

\begin{abstract}
ABSTRAK
Studi Kependudukan menjadi penting karena data semakin banyak digunakan untuk berbagai rencana pembangunan, dan memahami berbagai fenomena di masyarakat modern. Data sensus dan survei menjadi sumber utama kajian data kependudukan dalam Studi Kependudukan. Namun dalam kondisi darurat seperti terjadi perang atau konflik, bencana alam dan wabah penyakit maka pendataan secara tatap muka mungkin tidak dapat dilaksanakan secara tepat dan menyeluruh. Dalam kondisi ini sumber data lain yang dapat dimanfaatkan adalah dengan simulasi mikro menggunakan Agent Based Modelling (ABM). ABM adalah metode komputasional yang memungkinkan peneliti menciptakan, menganalisa, melakukan eksperimen dari suatu model yang terdiri dari sejumlah agen yang saling berinteraksi dengan lingkungan. Sehingga melalui simulasi mikro dengan ABM dapat diperoleh data populasi mikro, penjelasan fenomena sosial, prediksi dan estimasi kebutuhan pada suatu bidang. Berdasarkan kajian literatur diketahui ABM memiliki potensi besar untuk digunakan dalam penelitian Studi Kependudukan. Untuk itu paper ini bertujuan memperkenalkan dan menjelaskan tentang $A B M$, mengkaji potensi dan tantangan aplikasi ABM di bidang Studi Kependudukan. Sebuah ilustrasi aplikasi ABM tentang model penyebaran wabah COVID-19 dengan skema SusceptibleExposed-Infectious-Removed (SEIR) juga diberikan dalam paper ini untuk menunjukkan potensi ABM dalam perencanaan kebijakan kependudukan bidang kesehatan.
\end{abstract}

Kata kunci: Agent-Based Modelling, Studi Kependudukan, Potensi, Tantangan

\begin{abstract}
Population Studies is important as data are increasingly used for various development plans, and to understand various phenomena of modern societies. The main sources for analyzing population data in Population Studies are data from census and surveys. However, in emergency situations such as war or conflict, natural disasters and disease outbreaks, face-to-face approach in data collection may not be carried out accurately and thoroughly. In this condition, another data source that can be utilized is micro simulation with Agent Based Modelling (ABM). ABM is a computational method that allows researchers to create, analyze, experiment from a model consisting of a number of agents that interact with the environment. It means that through micro simulations with $A B M$ can be obtained micro population data, explanations of social phenomena, predictions and estimates of needs in a field. Based on the literature review, it is known that $A B M$ has great potential to be used in Population Studies research. Therefore this paper aims to introduce and explain $A B M$, examine the potential and challenges of $A B M$ application in the field of Population Studies. An illustration of the ABM application regarding the model of the spread of the COVID-19 outbreak with the Susceptible-Exposed-Infectious-Removed (SEIR) scheme is also given in this paper to show the potential of ABM in planning population policies in the health sector.
\end{abstract}

Keywords: Agent-Based Modelling, Population Studies, Potentials, Challenges 


\section{PENDAHULUAN}

Ilmu Demografi terbagi menjadi 2 yaitu Demografi Murni (Formal Demography) dan Studi Kependudukan (Population Studies) (Carmichael, 2016). Bogue (1969) dalam bukunya "Principle of the Demography" menyatakan Demografi Murni mempelajari secara statistik dan matematik tentang besaran, komposisi dan distribusi penduduk serta perubahannya sepanjang waktu melalui 5 komponen demografi yaitu fertilitas, mortalitas, perkawinan, migrasi dan mobilitas sosial. Sedangkan Studi Kependudukan yang juga dikenal sebagai Demografi sosial berupaya menjelaskan apa yang telah diungkap oleh Demografi Murni (variabel demografi) dan keterkaitannya dengan fenomena lain (variabel nondemografi). Kajian dalam Studi Kependudukan mencakup semua aspek dari pertumbuhan penduduk, dinamika dan distribusi penduduk termasuk juga aspek sosial budaya, ekonomi, politik dan masih banyak lagi. Demografi Murni memang menghasilkan teknik-teknik pengukuran indikator kependudukan namun tidak dapat menjelaskan mengapa suatu fenomena kependudukan terjadi. Keterbatasan ini sudah lama disadari, sebagaimana dinyatakan oleh Surapaty (1990) bahwa analisis Demografi Murni seringkali hasilnya terlalu akademis dan tidak dapat dimanfaatkan oleh pembuat kebijakan dalam rangka program rekayasa sosial. Hal-hal tersebut menunjukkan bahwa Studi Kependudukan memiliki cakupan lebih luas daripada Demografi Murni sehingga banyak demographer yang lebih menyukai pendekatan Studi Kependudukan dalam penelitiannya.

Secara tradisional, kajian data kependudukan dalam Demografi Murni dan Studi Kependudukan mengandalkan data sensus dan survei sebagai sumber data akibat registrasi penduduk di Indonesia belum terkelola secara baik. Pendataan Sensus dan survei yang dilakukan BPS dilakukan secara tatap muka atau door to door ke rumah penduduk. Namun dalam kondisi tertentu pendataan dengan sistem tatap muka tersebut tidak dapat dilakukan secara tepat dan menyeluruh akibat situasi tidak kondusif misalnya saat terjadi perang atau konflik, bencana alam dan wabah penyakit. Pada kondisi sulitnya pendataan sistem tatap muka, sumber data lain yang dapat dimanfaatkan adalah dengan simulasi mikro berbasis agen. Melalui simulasi mikro dengan Agent-Based Modelling (ABM) dapat diperoleh data populasi mikro, penjelasan fenomena sosial, prediksi dan estimasi kebutuhan pada suatu bidang. Hal ini dapat dilakukan karena ABM berusaha melihat suatu fenomena dan realitas dunia nyata dari perspektif kausalitas dinamik sehingga ABM dapat digunakan sebagai alat untuk menjelaskan, meng-explore ataupun membuat prediksi dalam mengambil keputusan di dunia nyata.

Sebenarnya sudah lebih dari 15 tahun yang lalu Billari dkk. (2003) dalam Bavel dan Grow (2017) merekomendasikan penggunaan ABM sebagai alat untuk memajukan teori kependudukan dan setelah itu berbagai artikel ilmiah tentang penggunaan ABM terbit di beberapa jurnal Demografi terkemuka, namun sayangnya ABM masih belum menjadi alat standar bagi para demographer dan kemajuan teori kependudukan melalui ABM masih terbatas. Macal dan North (2010) menyatakan ABM adalah suatu cara untuk memodelkan dinamika sistem yang kompleks dan sistem adaptif yang kompleks. Dengan sifat karakteristiknya tersebut, ABM memiliki kelebihan yaitu mampu secara fleksibel dan lebih baik untuk memodelkan sistem dunia nyata yang kompleks. Dinamika sosial atau perilaku kelompok orang termasuk sistem yang kompleks, ini terdapat pada bidang Studi Kependudukan, Sosiologi, Ekonomi, Psikologi dan Kesehatan.

Bonabeau (2002) mendefinisikan ABM sebagai teknik pemodelan simulasi dimana sebuah sistem dimodelkan sebagai kumpulan entitas pengambil keputusan yang otonom (yang disebut agen). Setiap agen bertindak secara individu dan mengambil keputusan berdasaran aturan yang sudah ditetapkan. Agen dapat menjalankan berbagai perilaku sesuai dengan sistem yang mereka wakili. ABM menggunakan pendekatan bottom-up untuk melihat bagaimana interaksi perilaku individu dapat mempengaruhi perilaku sistem dengan simulasi berbasis komputer. Beberapa contoh aplikasi $\mathrm{ABM}$ antara lain: dalam pemodelan dinamika penduduk urban, penyebaran penyakit, sistem biologis, kebakaran lahan dan evakuasi bencana.

Berdasarkan diskusi di atas, paper ini bertujuan memperkenalkan dan menjelaskan tentang ABM, mengkaji potensi dan tantangan aplikasi ABM di bidang Studi Kependudukan. Sebuah ilustrasi aplikasi ABM tentang model penyebaran COVID-19 dengan skema Susceptible-ExposedInfectious-Removed (SEIR) juga diberikan dalam paper ini untuk menunjukkan potensi ABM dalam 
penyusunan kebijakan kependudukan bidang kesehatan. Selain itu melalui paper ini diharapkan para demographer dan peneliti sosial dapat tertarik untuk menggunakan ABM dalam penelitiannya sehingga dapat ikut berkontribusi memajukan teori kependudukan dan memberikan input bagi kebijakan kependudukan. Terobosan dengan alat ABM pada Studi Kependudukan dianggap penting mengingat masalah kependudukan adalah salah satu tantangan paling serius yang dihadapi umat manusia di abad ke-21 dan intervensi kebijakan dalam masalah kependudukan membutuhkan analisis terintegrasi dan multidisiplin.

\section{METODE}

\section{Sejarah ABM}

Sejarah ABM berawal tahun 1940-an dari ide John von Neumman dan Stanislaw Marchin Ulam yang berkaitan dengan cellular automata (CA). CA adalah suatu pemodelan matematika sederhana dari suatu sistem fisik dimana ruang dan waktu sistem tersebut dijadikan diskrit. Kemudian hal ini membawa pada teori matematik tentang sistem partikel interaktif yang menggunakan metode mekanika statistika untuk mempelajari masalah-masalah yang berkaitan dengan perubahan fase dan sistem dinamika. Namun ABM baru mulai populer digunakan pada era tahun 1990-an untuk mensimulasikan dinamika fenomena sosial. Beberapa nama lain dari ABM antara lain IBM (Individual Based Modeling), ABS (Agent Based Simulation), dan MAS (Multi Agent System) namun semua nama tersebut mengandung pengertian yang sama dengan ABM.

\section{Apakah ABM?}

ABM adalah suatu model komputasi untuk mensimulasikan tindakan dan interaksi individu otonom yang disebut agen (dapat berupa orang, gedung, mobil, lahan, serangga dll) dalam sebuah grid bujursangkar yang sudah ditentukan dengan maksud untuk menilai efeknya pada sistem secara keseluruhan. Sebuah ABM biasanya didasarkan pada sekumpulan agen yang secara otonom mampu berinteraksi satu sama lain serta dengan lingkungan sesuai dengan aturan perilaku (yang bisa sederhana atau kompleks, deterministik atau stokastik, tetap atau adaptif). Elemen utama dalam pemodelan ABM adalah agen dan setiap agen bertindak dan berperilaku berdasarkan aturan yang dibuat didalam lingkungannya. Menurut Macal dan North (2010), ada 3 elemen dalam sebuah ABM yaitu:

d. Satu set agen, atribut dan perilaku mereka

e. Satu set relationship dan metode interaksi yaitu tipologi yang mendasari keterhubungan dan mendefinisikan bagaimana dan dengan siapa agen berinteraksi

f. Lingkungan (environment) agen. Agen berinteraksi dengan lingkungannya selain dengan agen-agen lain.

Artinya seorang pengembang model harus mengidentifikasi, memodelkan, dan memprogram ketiga elemen tersebut untuk membuat sebuah ABM. Konsep bagaimana agen bekerja secara sederhana disajikan pada Gambar 1. Agen ABM secara dinamis beradaptasi dan bereaksi terhadap lingkungan simulasi yang selalu berubah. Basis ABM adalah perilaku pemodelan dan mereka dapat dengan mudah mengambil efek umpan balik antara tingkat mikro dan makro, dan untuk alasan ini mereka muncul sebagai pelengkap yang ideal untuk model mikrosimulasi.

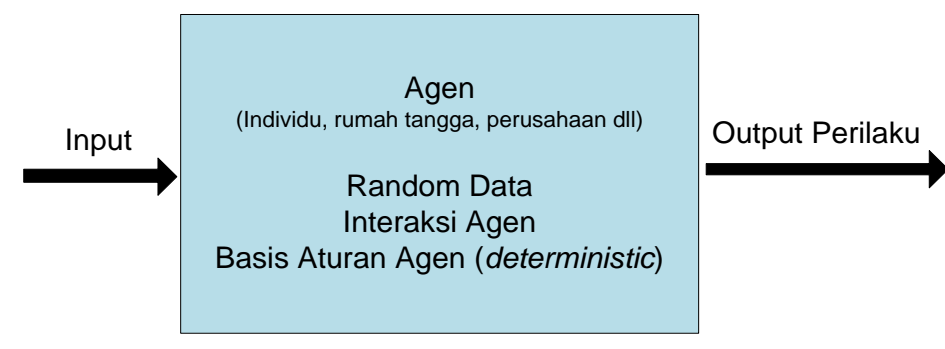

Sumber: (Singh dkk., 2015, hal. 336)

Gambar 50. Konsep simulasi dalam ABM

Beberapa program yang dapat digunakan untuk implementasi ABM adalah NetLogo, AnyLogic, Python, R, C++, Matlab, Mathematica, dsb. Namun NetLogo dianggap yang paling 1034 
lengkap dokumentasinya dan lebih praktis digunakan. NetLogo juga menyediakan alat bantu grafis untuk membuat antarmuka (interfaces) dengan cepat untuk menjalankan simulasi berbasis agen (lihat Gambar 2). Interface ini menjadi salah satu kelebihan dari Netlogo. Penjelasan lebih detil tentang penggunaan NetLogo untuk ABM diberikan oleh Berryman dan Angus (2010).

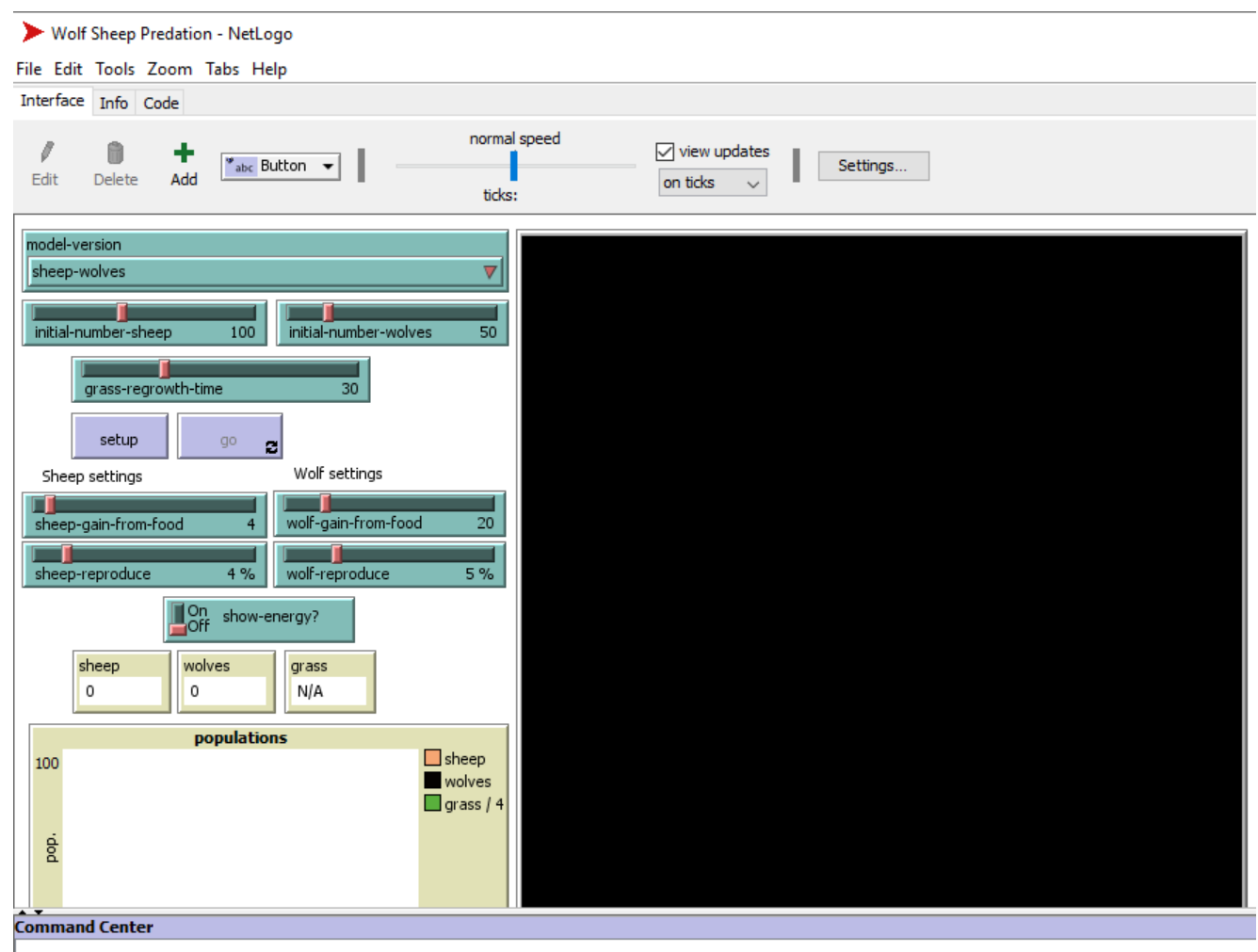

Gambar 2. Tampilan interface pada NetLogo untuk Skenario Predator Sheep versus Wolves

\section{Merancang ABM}

Pada dasarnya ada 3 tahap dalam merancang sebuah ABM yaitu: i) merancang model untuk menentukan komponen apa saja yang akan dimasukkan ke dalam model ii) membangun model dan iii) melakukan uji coba model. Model yang dirancang dapat berupa model berbasis fenomena atau model berbasis eksploratif. Satu contoh untuk model berbasis fenomena adalah model segregasi pemukiman Schelling. Model ini dibuat dari fenomena segregasi rasial yang selalu menjadi masalah di Amerika Serikat. Dari fenomena tersebut, pada tahun 1971, ekonom Amerika Thomas Schelling menciptakan model berbasis agen yang membantu menjelaskan mengapa segregasi begitu sulit untuk diberantas. Meski modelnya terbilang sederhana namun dapat memberikan gambaran yang menarik tentang bagaimana individu dapat memisahkan diri, bahkan ketika mereka tidak memiliki keinginan eksplisit untuk melakukannya.

Dalam ABM, Schelling's Model digambarkan dalam sebuah lingkungan dimana di dalamnya ada agen berwarna merah dan biru (lihat Gambar 3). Setiap kotak agen menggambarkan individu, katakanlah warna merah mewakili orang kulit putih dan warna biru mewakili orang kulit hitam. Setiap agen akan bergerak dan berjalan dengan pola sederhana yaitu mereka akan berusaha tinggal berdekatan dengan sebanyak mungkin warna yang sama dan menghindari agen dengan warna berbeda. Variabel lain yang dimasukkan dalam model ABM ini adalah tingkat kebahagiaan dari agen itu sendiri. Ketika agen berada dekat dengan warna yang sama maka tingkat kebahagiannya akan meningkat dibanding jika agen tinggal di lingkungan sekitar yang berbeda warna. Dibuat juga aturan kedua bahwa agen akan memutuskan untuk berpindah "rumah". Keputusan agen untuk tetap tinggal" atau "berpindah" rumah inilah yang kemudian menjadi "ambang toleransi" agen dalam menerima perbedaan ras dari tetangga terdekatnya. Simulasi ini terus bergerak sampai pada periode waktu tertentu yang bisa diatur sesuai keinginan penelitian. Hasilnya, dapat dilihat bagaimana pola segregasi sosial itu terbentuk dalam rentang waktu tertentu (lihat Gambar 3b) yang menunjukkan setelah 17 langkah terbentuk segregasi sosial. 


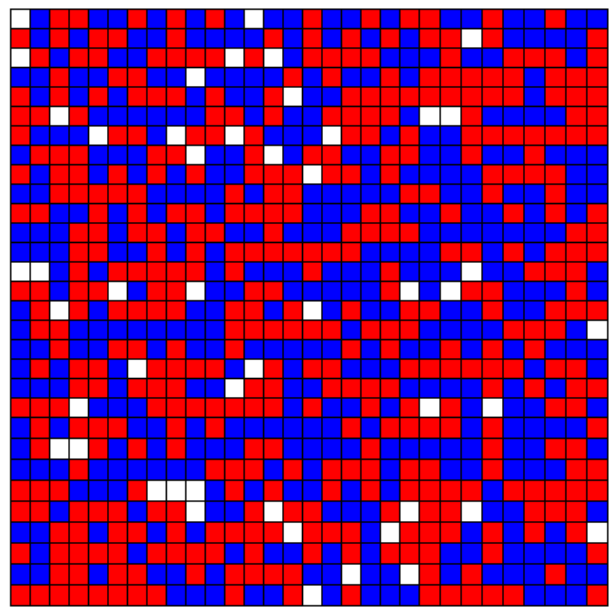

a. Awal simulasi

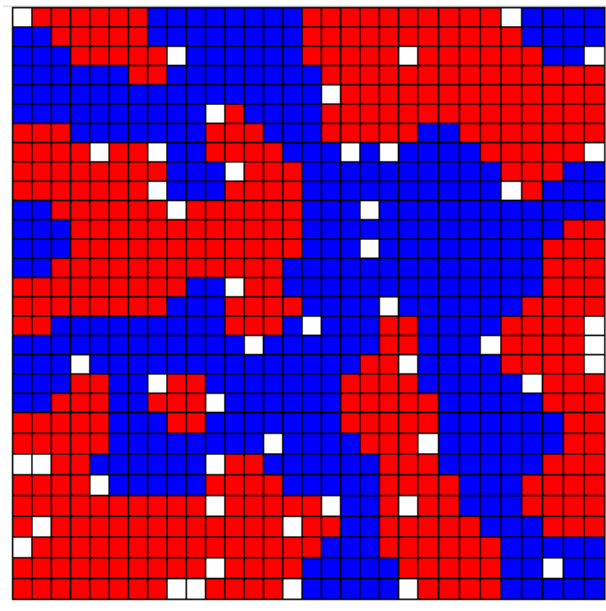

b. Setelah 17 langkah

Gambar 3. Contoh run dari model segregasi Schelling

\section{HASIL DAN PEMBAHASAN}

Hasil review literatur menunjukkan bahwa $A B M$ memiliki potensi yang cukup besar untuk membuktikan memajukan teori kependudukan. Namun demikian ABM juga memiliki beberapa tantangan yang harus dihadapi oleh para demographer dan peneliti sosial.

\section{Potensi}

Menurut Billari dkk. (2003) dalam Bavel dan Grow (2017) ABM dapat digunakan sebagai alat untuk memajukan teori kependudukan. Kelebihan ABM dalam memajukan teori kependudukan terletak pada kemampuannya menghubungkan level mikro dengan level makro. Bagaimana simulasi komputer dapat ikut memajukan teori kependudukan disajikan dalam Gambar 4. Namun tentu saja tetap dibutuhkan proses kalibrasi ABM dengan data empiris. Kelebihan ABM lainnya adalah mampu memodelkan sistem dinamika sosial yang kompleks misalnya perilaku kelompok tertentu dalam memilih pemimpin saat pilkada.

Gambar 4. Hubungan antara teori kependudukan dan simulasi komputer

\section{Tantangan}

Menurut Prskawetz (2017), tantangan dalam membangun sebuah ABM adalah menentukan karakteristik dan aturan untuk agen dan kemudian mendefinisikan bagaimana agen berinteraksi dan bagaimana perilaku ekonomi makro dapat memberi umpan balik pada proses keputusan tingkat mikro. Penentuan ini sedapat mungkin harus berdasarkan bukti empiris. Lebih lanjut Prskawetz menyatakan bahwa dalam membangun ABM juga dibutuhkan pengetahuan yang cukup tentang simulasi komputer, statistika dan teori peluang. Selain itu menurut Billari et al. (2003) dalam Bavel \& Grow (2017) satu faktor penting yang menjadi penghalang aplikasi ABM secara luas dalam Studi Kependudukan adalah kurangnya teori. Padahal penerapan ABM justru dilakukan dengan cara memasukkan teori aturan perilaku, pengambilan keputusan dan interaksi dalam simulasi dan kemudian mengamati pola yang dihasilkan dari simulasi tersebut. Hal ini yang 1036 
menjadi suatu tantangan karena di satu sisi untuk menerapkan ABM perlu teori, namun di sisi lain penerapan $\mathrm{ABM}$ bertujuan mengembangkan teori-teori kependudukan yang dianggap masih kurang.

\section{Contoh Ilustrasi Penggunaan ABM}

Mobilitas penduduk menjadi salah satu faktor pendorong dalam memperluas penyebaran COVID-19. Penyebaran yang sangat cepat ditandai dengan kurva kasus baru yang memiliki puncak yang lebih tinggi atau puncak kasus terjadi lebih cepat. Hal ini memberikan implikasi pada kesiapan sumber daya kesehatan yang tersedia. Jika kasus yang memerlukan penanganan lebih besar daripada sumber daya yang tersedia, maka pelayanan kesehatan terkait penanganan COVID-19 akan tumbang. Penerapan physical distancing (jaga jarak) ataupun pembatasan mobilitas adalah salah satu intervensi untuk memperlambat penyebaran COVID-19. Seperti halnya DKI Jakarta yang per 14 September 2020 kembali memberlakukan pembatasan sosial berskala besar (PSBB) karena disinyalir kapasitas rumah sakit tempat perawatan pasien COVID-19 yang semakin terbatas (Kompas TV, 2020).

Berkaitan dengan hal tersebut, berikut ini diberikan sebuah contoh sederhana aplikasi ABM pada model penyebaran COVID-19 dengan skema SEIR yang dapat menjelaskan bagaimana physical distancing dapat berpengaruh terhadap penyebaran COVID-19. Model ini mengadopsi model epidemiologi SEIR yang membagi proses penularan penyakit ke dalam empat fase, yakni: rentan, terpapar, terinfeksi, dan sembuh. Dalam suatu populasi, individu (agen) rentan akan memasuki fase terpapar jika mengalami kontak dengan agen yang terinfeksi. Kontak dalam hal ini dapat berupa kontak langsung maupun kontak secara tidak langsung atau berada pada jarak yang terlalu dekat (dalam radius tertentu). Agen yang terpapar selanjutnya akan mengalami gejala dan memasuki periode infeksi setelah melalui masa inkubasi virus. Masa inkubasi COVID-19 diasumsikan selama 4 sampai dengan 14 hari (Lauer, Grantz, Bi, \& Jones, 2020). Agen akan sembuh setelah terinfeksi selama 2 sampai dengan 3 minggu (WHO, 2020). Agen yang telah terinfeksi dan sembuh diasumsikan tidak dapat terinfeksi kembali. Diagram alir untuk fase infeksi disajikan pada Gambar 5.

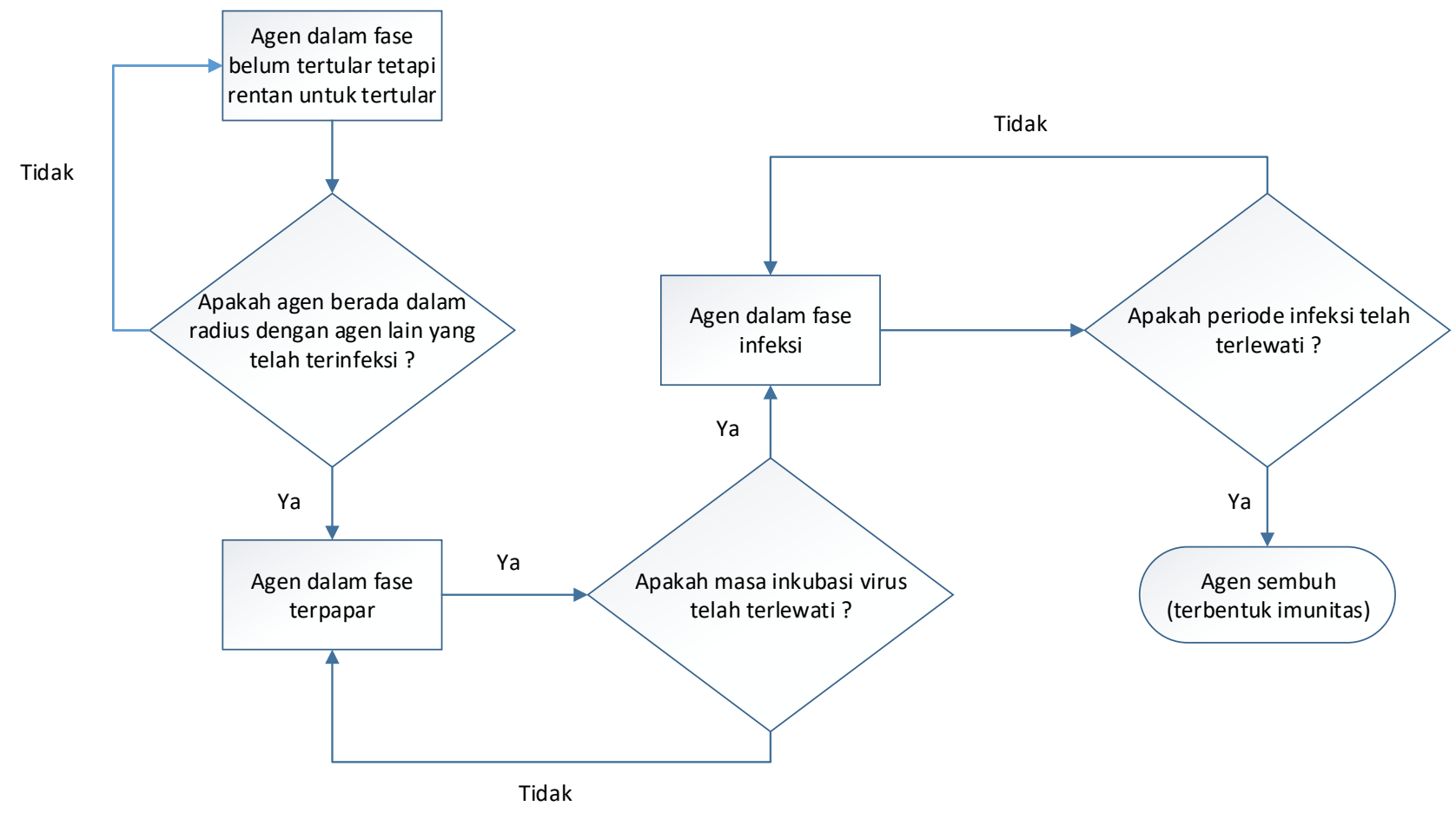

Sumber: diadopsi dari Perez and Dragicevic (2009)

Gambar 5. Diagram alir fase infeksi COVID-19 yang disimulasikan 
Setiap agen memiliki atribut status fase: rentan, terpapar, terinfeksi, dan sembuh; masa inkubasi; masa infeksi, dan status melakukan physical distancing. Implementasi model menggunakan NetLogo dengan parameter input: ukuran populasi, banyaknya agen yang terinfeksi awal, persentase agen rentan yang melakukan pembatasan sosial dan radius penularan antar agen. Gambar 6 adalah tampilan tatap muka (user interface) untuk model yang diimplementasikan. Ilustrasi pengaruh physical distancing terhadap penyebaran COVID-19 akan ditunjukkan dengan proses simulasi dengan parameter input: ukuran populasi sebesar 200 agen, 2 agen yang terinfeksi awal, dan radius penularan 0,9 meter (jaga jarak aman yang dianjurkan 1 meter). Parameter persentase agen yang melakukan physical distancing dicobakan ke dalam dua level: 0\% (tanpa physical distancing), dan 80\% (dengan physical distancing). Durasi waktu yang disimulasikan adalah 200 hari. Perilaku hasil simulasi untuk setiap skenario disajikan pada Gambar 7.

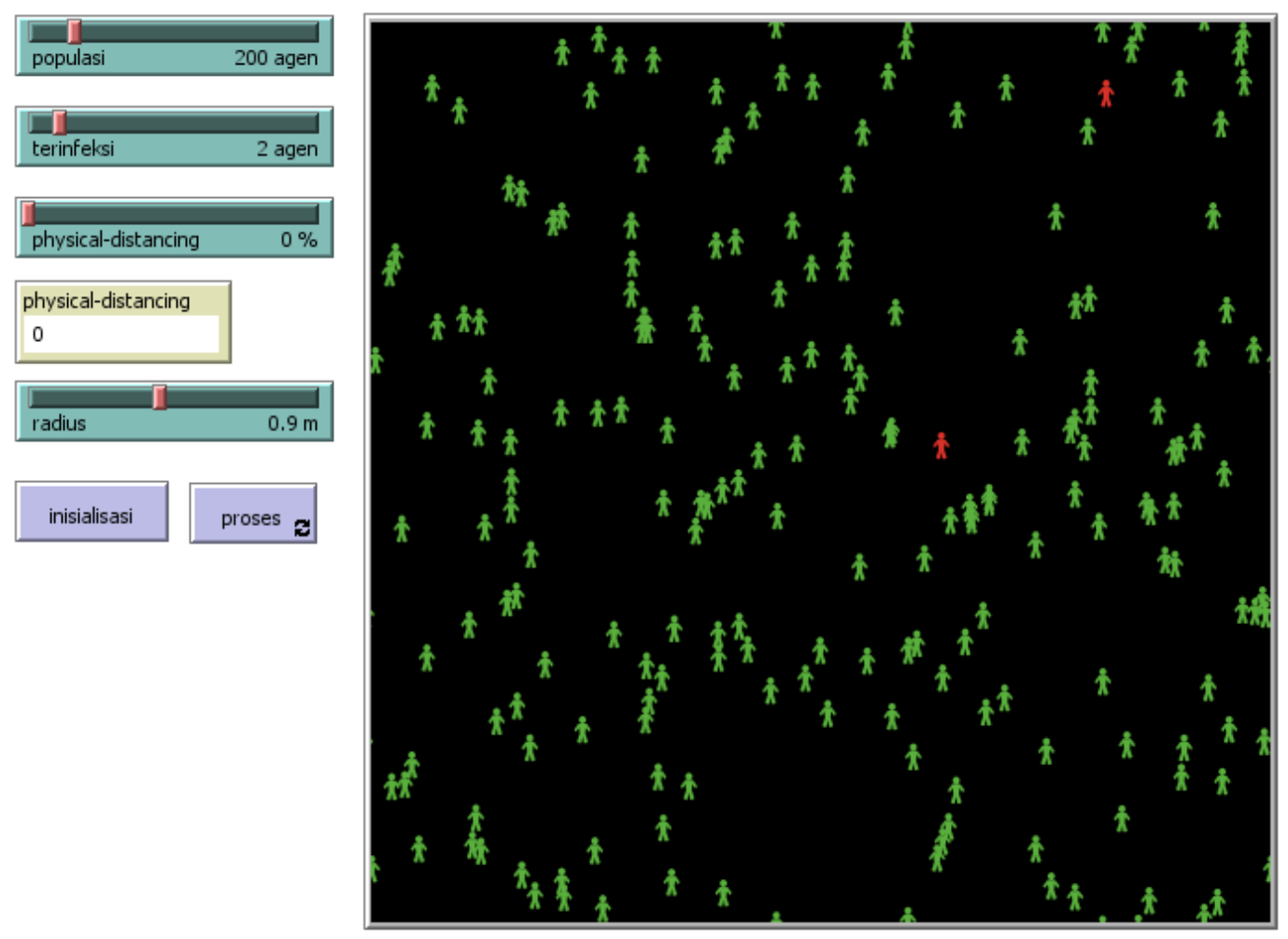

Gambar 6. Antar muka (interface) model penyebaran COVID-19 skema SEIR

Berdasarkan Gambar 7, simulasi model ABM dengan physical distancing dan tidak adanya physical distancing menunjukkan hasil yang berbeda terhadap penyebaran COVID-19. Perilaku yang ditunjukkan sesuai dengan pernyataan sebelumnya bahwa tanpa physical distancing, puncak kasus terjadi lebih cepat namun dengan jumlah yang lebih tinggi. Sedangkan physical distancing dapat menekan kecepatan penyebaran sehingga puncak kasus lebih rendah, bahkan ada agen yang tidak terpapar sehingga tidak mengalami infeksi. Selain digunakan untuk melihat pengaruh physical distancing, model tersebut juga dapat digunakan untuk melihat pengaruh kepadatan penduduk terhadap penyebaran COVID-19 dengan mencobakan parameter ukuran populasi pada beberapa level yang berbeda. Lebih lanjut dapat dicobakan dengan user interface yang telah kami buat (https://aripurwantosp.github.io/abmcovid-19seir/). Model yang diimplementasikan adalah contoh model ABM sederhana yang bertujuan untuk memberikan ilustrasi supaya dapat dengan mudah dipahami. Tentu saja, model yang diilustrasikan dapat dikembangkan lebih lanjut untuk memodelkan sistem yang lebih mendekati kenyataan dengan cara melakukan penyesuaian 
terhadap keadaan populasi, atribut, aturan. Penyesuaian-penyesuaian tersebut dapat dilakukan berdasarkan informasi primer maupun informasi sekunder yang tersedia.

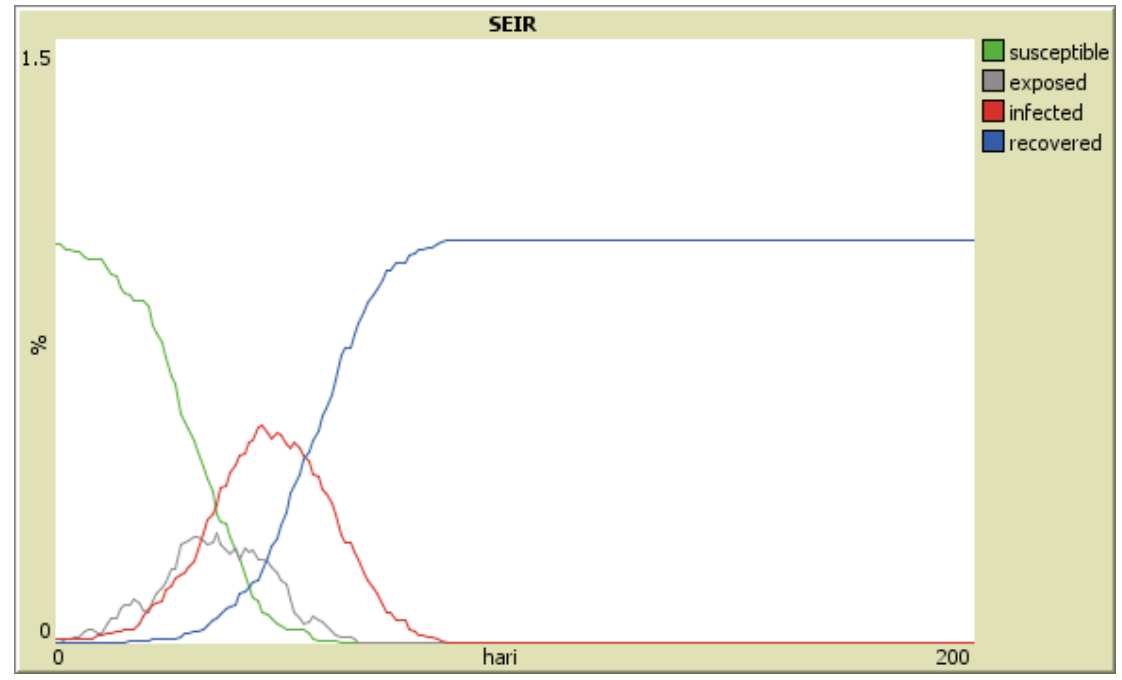

(a)

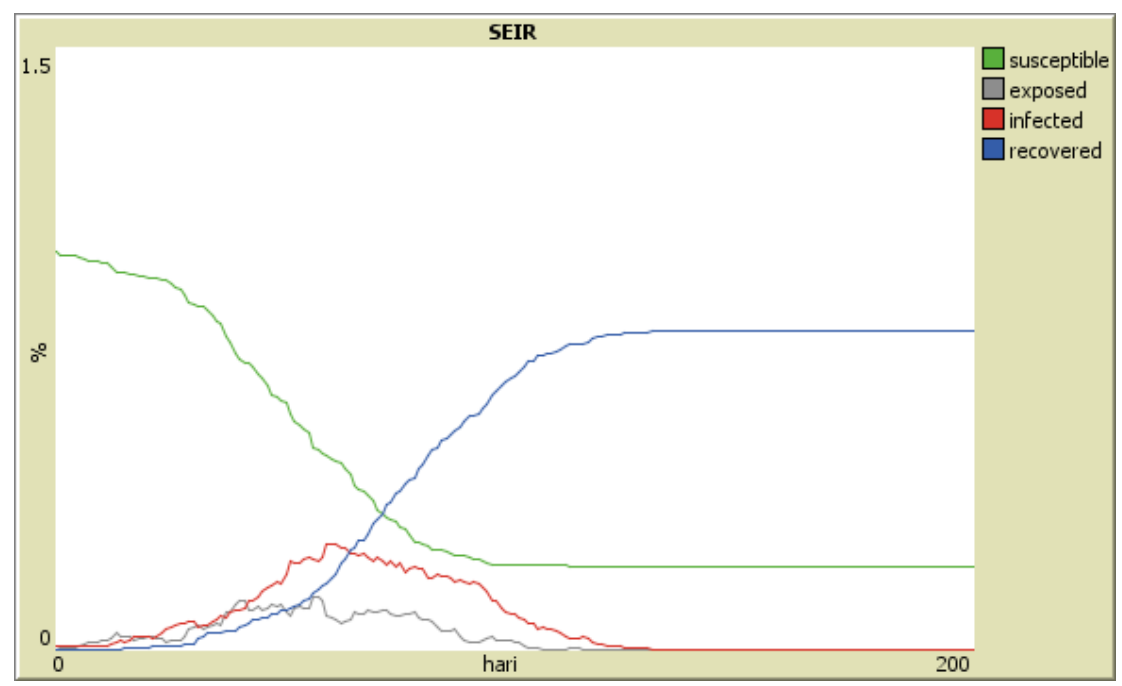

(b)

Gambar 7. Perilaku simulasi penyebaran COVID-19 dengan tanpa physical distancing (a) dan physical distancing level $80 \%$ (b)

\section{KESIMPULAN}

Potensi ABM dalam Studi Kependudukan terletak pada kemampuannya menghubungkan level mikro dengan level makro guna memajukan teori-teori kependudukan. Termasuk juga kemampuan ABM dalam memodelkan sistem dinamika sosial yang kompleks. Namun demikian masih ada faktor penghalang aplikasi ABM dalam Studi Kependudukan yaitu masih kurangnya teori yang ada. Pada akhirnya sebuah ilustrasi aplikasi ABM dalam model penyebaran COVID-19 yang disajikan dalam paper ini telah berhasil menunjukkan pentingnya melakukan physical distancing untuk menurunkan tingkat penyebaran COVID-19 di Indonesia.

\section{DAFTAR PUSTAKA}


Bavel, J. von, \& Grow, A. (2017). Introduction: Agent-Based Modelling as a Tool to Advance Evolutionary Population Theory. In Bavel, J. von \& A. Grow (Eds.), Agent-Based Modelling in Population Studies: Concepts, Methods, and Applications (pp. 3-27): Springer International Publishing Switzerland.

Berryman, M.J. \& Angus, S.D (2010). Tutorials on Agent-based Modelling with NetLogo and Network Analysis with Pajek. World Scientific Lecture Notes in Complex Systems, pp. 351-375. doi: 10.1142/9789814277_0010

Billari, F. C., Prskawetz, A., Diaz, B. A., \& Fent, T. (2007). The "Wedding-Ring": An agent-based marriage model based on social interaction. Demographic Research, 17(3), 59-82. doi: 10.4054/DemRes.2007.17.3

Bogue, D. J. (1969). Principles of Demography. New York: John Wiley and Sons, Inc.

Bonabeau, E. (2002). Agent-based modeling: Methods and techniques for simulating human systems. Proceedings of the National Academy of Sciences, 99(suppl 3), 7280-7287. doi: 10.1073/pnas.082080899

Carmichael, G. A. (2016). Fundamentals of Demographic Analysis: Concepts, Measures and Methods. Springer International Publishing.

Kniveton, D., Smith, C., \& Wood, S. (2011). Agent -based model simulations of future changes in migration flows for Burkina Faso. Global Environment Change, 21, S34-S40. doi: 10.1016/j.gloenvcha.2011.09.006.

Kompas TV. (2020). Anies: Alasan PSBB Lagi, RS DKI Terancam Penuh 17 September. Diakses 16 September, 2020, dari https://www.kompas.tv/article/107860/anies-alasan-psbb-lagi-rs-dkiterancam-penuh-17-september

Lauer, S. A., Grantz, K. H., Bi, Q., \& Jones, F. K. (2020). The Incubation Period of Coronavirus Disease 2019 (COVID-19) From Publicly Reported Confirmed Cases: Estimation and Application. Annals of Internal Medicine, 172(9), 577-582. doi: 10.7326/M20-0504

Macal, C. M., \& North, M. J. (2010). Tutorial on agent-based modelling and simulation. Journal of Simulation, 4, 151-162. doi: 10.1057/jos.2010.3

Perez, L., \& Dragicevic, S. (2009). An agent-based approach for modeling dynamics of contagious disease spread. International Journal of Health Geographics, 8(50). doi: 10.1186/1476-072X-8-50

Prskawetz, A. (2017). The Role of Social Interactions in Demography: An Agent-Based Modelling Approach. In Bavel, J. von \& A. Grow (Eds.), Agent-Based Modelling in Population Studies: Concepts, Methods, and Applications (pp. 53-72): Springer International Publishing Switzerland.

Schelling, T. C. (1971). Dynamic models of segregation. Journal of Mathematical Sociology, 1(2), 143-186.

Singh, K., Sajjad, M., \& Ahn, C. (2015). Simulating Population Dynamics with an Agent Based and Microsimulation Based Framework. Paper presented at the International Conference on Applied Social Science Research (ICASSR 2015).

Surapaty. (1990). Kependudukan: Menuju Suatu Ilmu Kemanusiaan Terpadu. Populasi, 1(2), 1-10.

WHO. (2020). Report of the WHO-China Joint Mission on Coronavirus Disease 2019 (COVID-19). 